\title{
The Impact of Available Nitrogen Deficiency on Long-Term Changes in the Lake Kinneret Ecosystem
}

\author{
Moshe Gophen \\ Migal-Scientific Research Institute, Kiryat Shmone, Israel \\ Email: Gophen@Migal.org.il
}

Received 22 February 2015; accepted 1 April 2015; published 8 April 2015

Copyright (C) 2015 by author and Scientific Research Publishing Inc. This work is licensed under the Creative Commons Attribution International License (CC BY). http://creativecommons.org/licenses/by/4.0/

\begin{abstract}
Lake Kinneret Ecosystem structure has undergone significant modification since early 1990s. Scientists have indicated several causative factors for those long-term changes. The sharp decline of Peridinium and the upset of Cyanobacteria are the major changes. Several options were suggested as the reason for those changes. Among others are the followings: high amplitude of water level fluctuations, global warming, fisheries management, salts diversion, onset and offset of beach vegetation, anthropogenic operations in the drainage basin, allelopathic trait of algal competition, etc. It was suggested that the reduction of ammonia supply from the Hula Valley resulted in the conversion of the land from lake and swamps covered to agriculture followed by elimination of treated domestic sewage and fishponds effluents enhanced deficiency of available $\mathrm{N}$ in Lake Kinneret. This paper evaluates the impact of available Nitrogen decline which enhanced Kinneret ecosystem modifications.
\end{abstract}

\section{Keywords}

Kinneret, Peridinium, Ammonia, Hula Valley

\section{Introduction}

Lake Kinneret is the only natural freshwater lake in Israel located in the Syrian-African rift valley in northern Israel. Above $95 \%$ of the Israeli natural water resources are utilized. The total national water budget $\left(2.11 \times 10^{9}\right.$ $\mathrm{m}^{3}$; bcm), includes $0.55 \mathrm{bcm}$ from the Kinneret-Jordan system, and $0.7 \mathrm{bcm}$ from desalination plants [1] [2]. The lake and its drainage basin have undergone severe natural and anthropogenic changes: the construction of the south dam (1933), and the National Water Carrier (NWC) (1950s) enabling water supply. During the last 49 
years, the NWC system removed approximately $15 \mathrm{bcm}$ of water from the lake (ca 3.8 times the lake volume) for drinking, agriculture, industry and aquifers recharging [3]-[5].

As a result of over utilization and natural droughts, the Water level in the lake fluctuated at an amplitude of approximately 6 meters. The lake is also under heavy fishery utilization and fishery management including introduction of native and exotic species [6] [7]. Salts diversion was carried out and the lake water chloridity fluctuated between 210 and 300 ppm chloride. Hula Old Lake and Swamps in the Hula Valley (drainage basin) were drained [4] and domestic sewage was eliminated from the Kinneret inputs and fishpond effluents were reduced dramatically [8] [9]. Agricultural practices in the catchment area were changed also. Regional air temperatures and consequently lake water were increased and heat balance and precipitations were modified. Changes of phytoplankton composition and density within the Kinneret ecosystem were documented. When anthropogenic and natural changes are accompanied by both eutrophication and global changes, it is possible that impact reinforcement of each other is carried out. Consequently, the evaluation of the process dynamics involved in the transition of Lake Kinneret ecosystem between different structures may be confounded and/or misleading. Longterm changes in the subtropical Lake Kinneret were widely documented followed by impact evaluations of climate changes and anthropogenic factors. The major criteria of impact were mostly related to water level fluctuations constrained by water consumption and droughts. In this paper, I present an attempt aimed at sole element of ecological trait, available Nityrogen, which might be the dominant factor which enhances the recorded changes.

\section{Material and Methods}

The data of phytoplankton, and nutrients in Lake Kinneret and River Jordan were taken from the Lake Kinneret Data Base [9] [10] and the annual reports of The Kinneret Limnological Lboratory [10]. To exemplify the reservoir ecosystem structure a monitoring program in three of them, 2 years after their operation was carried out. These reservoirs are located along the western side of the Hula Valley within the drainage basin and collect domestic sewage and natural runoff waters. The monitoring program was carried on a monthly basis. These reservoirs were, from north to south, Kiryat Shmone $\left(1 \mathrm{~m}\right.$ deep, volume $\left.1 \times 10^{6} \mathrm{~m}^{3}\right)$, Amiad $(1.5 \mathrm{~m}$ deep, volume 0.3 $\times 10^{6} \mathrm{~m}^{3}$ ) and Einan (15- $18 \mathrm{~m}$ deep, volume $5.6 \times 10^{6} \mathrm{~m}^{3}$ ). The following parameters were recorded: $\mathrm{DO}, \mathrm{pH}$, and temperature of surface water (YSI detector); samples were collected for further lab. analysis of chlorophyll concentration (was multiplied by 250 for biomass conversion), microbial plate counting (Total Coliform Bacteria, Aeromonas, and Intestinal Enterococci) and Zooplankton densities.

The Statistical evaluations were done by Linear Regressions (Simple and Polynomial); ANOVA $(p<0.05)$; LOWESS-0.8; Fractional Polynomial and Linear Prediction; paired-t-Test; (Stata-Statistical Data Analysis 9.1, and StatView 5.1).

\section{Results}

\subsection{Reservoir Ecology (Figure 1, Figure 2)}

Data collected by monthly sampling in the three reservoirs included: Surface water Temperature, pH, DO, BOD. 5, Chlorophyll (algal biomass was computed by multiplication of chlorophyll concentration values by 250). The annual rain gauges measured in the drainage basin of Lake Kinneret during the last 21 years indicates a significant $\left(r^{2}=0.389 ; p=0.0025\right)$ relation with calculated quantities of available water in Lake Kinneret (input minus evaporation) [8]. Moreover, the annual reservoirs overflows also represent significant relation with available waters $\left(r^{2}=0.493 ; p=0.0004\right)$. Therefore, the obvious relation between rain regime and the overflow of extra treated sewage beyond maximum reservoirs capacity into Lake Kinneret is concluded. The results of the reservoir monitoring are presented in Figure 1, Figure 2. The multi-annual average of TN concentration during 21 years (1998-2013) was calculated as $42.5 \mathrm{ppm}$ [8].

Statistical evaluation of the data indicated the followings: Paired t-test clearly proved similarity between Ks and Ami reservoirs $(p=0.3415)$ and Ami and Ein $(p=0.2893)$ but significant difference between KS and Ein reservoirs $(p=0.0162)$. Consequently a gradiant trait from KS at top northern through the mid location of Ami to the southern end located Ein. The three reservoirs are connected by the drainage Western canal flowing from north (KS) to south (Ein). Dissimilarities between the Phytoplankton Biomass concentration and BOD.5 values in the three reservoirs were documented. Nevertheless, due to Chemo-Physical parameters of surface waters Temp., DO at $0.5 \mathrm{~m}$ depth, and $\mathrm{pH}$ good correlations were documented between the three reservoirs with lower 

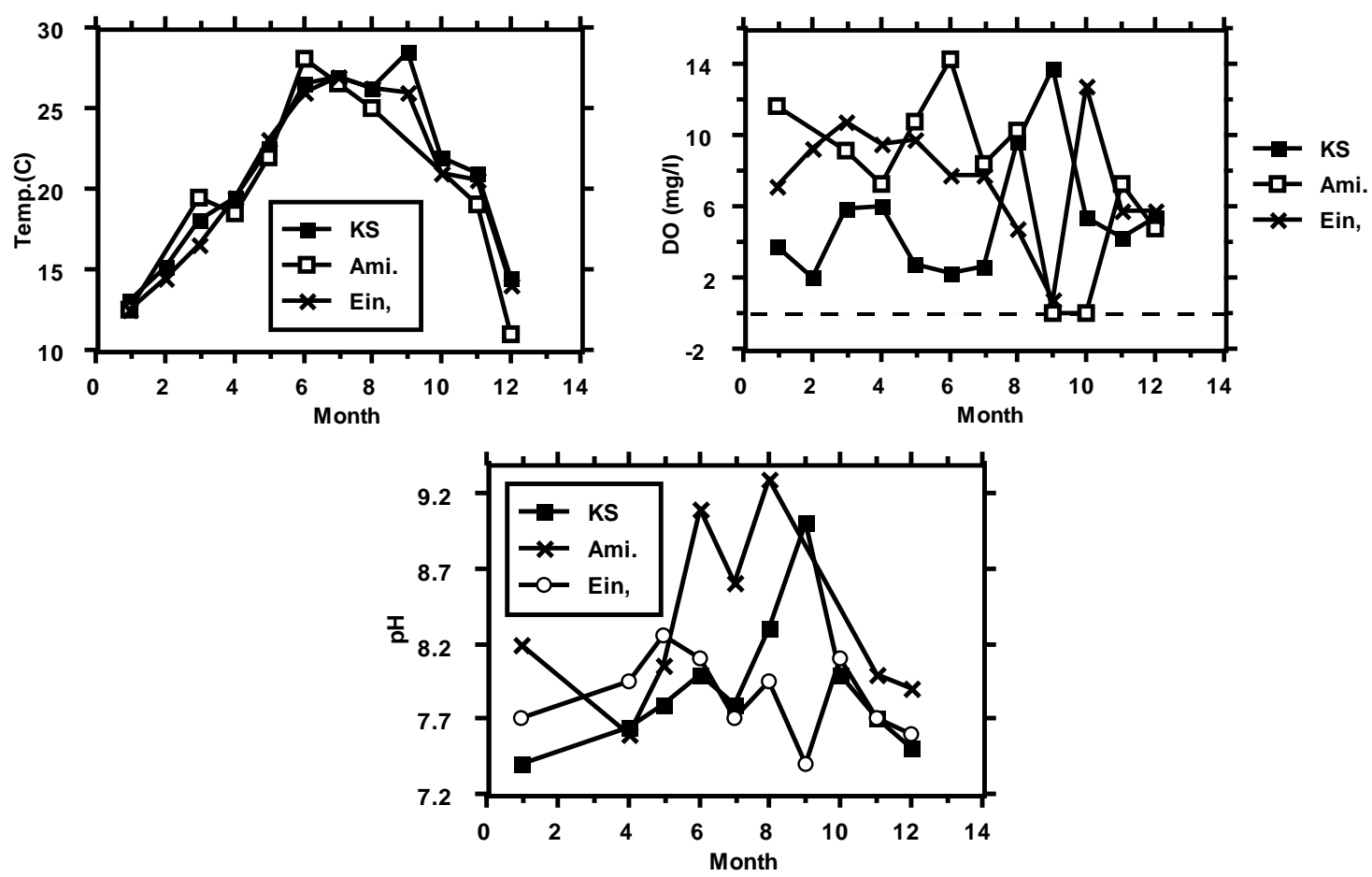

Figure 1. Monthly changes of surface temperature $\left({ }^{\circ} \mathrm{C}\right), \mathrm{pH}$ and DO (ppm) in three reservoirs: Kiryat Shmone (KS), Amiad (Ami) and Einan (Ein).
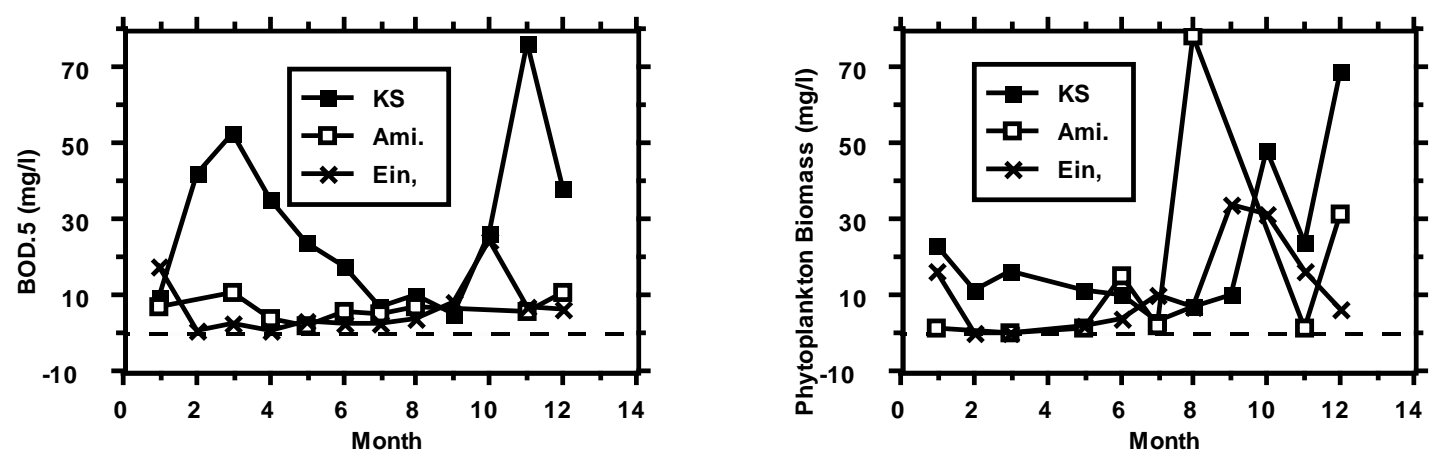

Figure 2. Monthly changes of BOD-5 (ppm), and phytoplankton biomass (mg/l) in surface water in three reservoirs: Kiryat Shmone (KS), Amiad (Ami) and Einan (Ein).

levels in Ein reservoir. Statistical evaluations of Simple regression to analyze the relations between biological and chemo-physical parameters of each reservoir indicated significant correlations between $\mathrm{pH}$ and DO whilst all others were in-significant. Conclusively it can be indicated that even if the reservoirs are located close to each other and collect similar effluents composition the internal bio-chemical rate of processes are not necessarily similar. The zooplankton assemblages were monitored as well. It was found that the most common animals were small Rotifers (60 - 8000/l) (Brachionus spp., Polyarthra spp., Pedalia sp., Filinia sp., Collotheca sp., and very few Asplanchna sp.). Cladocerans (Ceriodaphnia spp., Bosmina spp., Moina sp., Daphnia sp.) (2 - 20/l) were rarely found. Cyclopoid and Calanoid Copepods (adults and nauplii) were documented mostly in Ein reservoir. Input of treated sewage if considered as positive component to be fluxed into natural freshwater lakes the common and obvious response is "not" and "removal" but their available Nitrogen content might be helpful when a lake is under $\mathrm{N}$ deficienc. Treated sewage removal policy is mostly due to existence of poathogens. The presence of bacteria in those three reservoirs was carefully monitored. Aeromonas was found in the three reservoirs at the level of 2 - $5 \times 10^{3}$ per $100 \mathrm{ml}$; Enterococcus $-6-3 \times 10^{3}$ per $100 \mathrm{ml}$; and Fecal Coliformes-1 - 50 $\times 10^{3}$ per $100 \mathrm{ml}$. Consequently, if treated sewage is proposed as nutrients source, pathogens should be consi- 
dered primarily.

\subsection{Nutrients Dynamics and Regime in River Jordan}

The nutrient dynamics in the Jordan were statistically evaluated and the results are given in Table 1 [9] [10].

Results given in Table 1 indicates that most of the reduced nutrients (TP, Kjt, Org.N, and $\mathrm{NH}_{4}$ ) during 19882014 are those originated from domestic sewage. All nutrients (loads and concentrations) during 1988-2004 were lower than in previous period, except Nitrate. Moreover, these declines were statistically significant except for TN (load and concentration) and Organic N (concentration). It is probable that the significant lower load of organic $\mathrm{N}$ resulted in by the lower discharge because the concentration decline was insignificant. The decline of discharge during 1988-2004 slightly contributed to the loads reductions and the lower concentration during the second period is prominently documented. Kinneret Authority Reports [8] documented reservoirs storage capacity of $18 \times 10^{6} \mathrm{mcm} /$ year (Million Cubic Meters) for domestic and diary sewage produced in the Lake Kinneret drainage basin of which $1.1 \times 18 \times 10^{6} \mathrm{mcm} /$ year is overflow to the lake and $33 \%\left(6 \times 18 \times 10^{6} \mathrm{mcm} /\right.$ year $)$ is utilized by farmer for irrigation. The concentration of TN in the sewage is averaged (Green 2013) as 42.5 (SD 16.2) ppm. Consequently more than 700 tons of $\mathrm{TN}$ is diminished from the Kinneret load annually and stay in reservoirs or in farm land. It should be accounted that this reduced Nitrogen is mostly Organic and ammonia. One more significant source of ammonia and Organic Nitrogen were effluents from fishponds located in the Hula Valley. The total area of fishponds was significantly reduced during the 1980s from 1700 ha to less than 500 ha presently. It was obviously accompanied by reduction of Nitrogen rich effluents inputs to Lake Kinneret.

\subsection{Nitrogen Deficiency, Peridinium Offset and Cyano-Bacteria Onset (Figures 3-6)}

The Hula swamps and Old Lake were drained during the 1950s. There is little data about nutrient content and quantitative inputs from the drainage area into Lake Kinneret [11] [12]. Routine monitoring and eco-physiological investigations of the seasonal, bathymetrical and spatial distribution of the bloom forming dinoflagelat algae Peridinium gatunense (previously: cinctum fa. westii) initiate in late 1960s [13]-[15]. Routine qualitative and

Table 1. Comparative ANOVA test $(p<0.05)$ between two periods: 1$)$ 19701987; 2) 1988-2004 parameters are total averages of monthly loads ( ton) and concentration (ppm) of nutrient fluxes in River Jordan (station Huri Bridge); Jordan Discharge $\left(10^{6} \mathrm{~m}^{3}\right.$ per month: $\left.\mathrm{mcm} / \mathrm{m}\right)$. ${ }^{*}$ Significant, ${ }^{* *}$ Not Significant. Org. $\mathrm{N}$ = Organic Nitrogen, Kjt = Total Kijeldhal; $\mathrm{P}=$ Probability.

\begin{tabular}{cccc}
\hline Parameter & $1970-1987(1)$ & $1988-2004(2)$ & $p$ \\
Ton/month & & & \\
$\mathrm{TP}$ & 8.9 & 5.6 & $0.0003^{*}$ \\
$\mathrm{TN}$ & 118 & 106 & $0.4354^{* *}$ \\
$\mathrm{Kjt}$ & 40 & 22 & $<0.0001^{*}$ \\
$\mathrm{NO}_{3}$ & 78 & 84 & $0.6690^{* *}$ \\
Org.N & 35 & 20 & $<0.0001^{*}$ \\
$\mathrm{NH}_{4}$ & 5.2 & 2.7 & $<0.0001^{*}$ \\
$\mathrm{ppm}$ & & & \\
$\mathrm{TP}$ & 0.213 & 0.141 & $<0.0001^{*}$ \\
$\mathrm{TN}$ & 2.7 & 2.5 & $0.0671^{* *}$ \\
$\mathrm{Kjt}$ & 1.1 & 0.6 & $<0.0001^{*}$ \\
$\mathrm{NO}_{3}$ & 1.65 & 1.95 & $0.0008^{*}$ \\
Org.N & 0.93 & 0.51 & $<0.0001^{* *}$ \\
$\mathrm{NH}_{4}$ & 0.133 & 0.072 & $<0.0001^{*}$ \\
Discharge (mcm/m) & 40 & 34 & $0.0169^{*}$ \\
\hline & & &
\end{tabular}


quantitative monitoring of Nutrient fluxs into Lake Kinneret through River Jordan (Water Supply Company, Mekorot) was started in early 1960s [9]. Data collected about Nitrogen concentration in the old Lake Hula and Swamps is given in [11]. Percy Sladen [11] [12] summarized results of expedition to the Hula Valley carried out during 1935-1936 and reported the concentrations of Free Ammonia, Albumenoid Ammonia, Nitrate, and Nitrit he measured. These date prominently indicate no Nitrate presence and only traces of Nitrit but high concentrations of free Ammonia (0.45 and $0.06 \mathrm{ppm}$ in the swamp waters and Hula Lake respectively) and Albuminoid Ammonia (0.18 and $0.30 \mathrm{ppm}$ in the Lake Hula and Swamps respectively). The total Ammonia content is therefore $0.24 \mathrm{ppm}$ and $0.75 \mathrm{ppm}$ in the Hula Lake and swampa respectively. It can be concluded that the Old Lake Hula and the swamps were a great Ammonia storage capacity to be supplied to Lake Kinneret. The physiology of Peridinium in Lake Kinneret was intensively studied. Similar studies were dedicated to the fate of Nitrogen migration into Lake Kinneret. Nitrogen dynamic in Lake Kinnerert indicates a pattern of maximum load (monthly peak) in March and minimal level in August. Figures 4-6 represent the annual decline from March to August and multi-annual decline as well. The annual dissipation exponent of total nitrogen is compatible to the level of maximum load of TN in the epilimnion. If the load is high the exponent is higher as well. Consequently, the input of Nitrogen in the next winter is the most effective source to complete the nitrogen demands by potential consumers. The top priority of nitrogen supply was due to Peridinium. Therefore severe damage caused by Nitrogen deficiency primarily affected the Peridinium bloom formation (Figures 7-9). As a result of Nitrogen input decline and consequently reduction of Nitrogen supply to the Kinneret biota (Figures 3-6) other algae flourished [16] (Figures 7-9). The first to flourish were Cyano-bacteria (Figure 9) and mostly those genera of $\mathrm{N}_{2}$ fixing bacterium like Aphanizomenon sp. and Cylindrospermopsis spp. Moreover, as a result of Phosphorus sufficiency Di-atoms and Chlorophyta also flourished. The cardinal question to be answered is: why Nitrogen

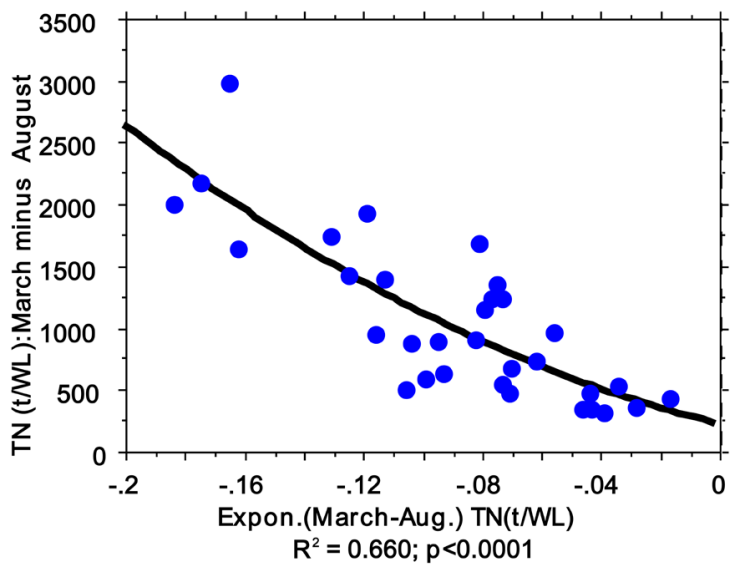

Figure 3. Polynomial regression $\left(\mathrm{r}^{2}\right.$ and $p$ values are given) between TN monthly load difference between March (annual peak) and August (annual minima) (1970-2005 averages) and the dissipation exponent. Data source: LKDB-KLL.
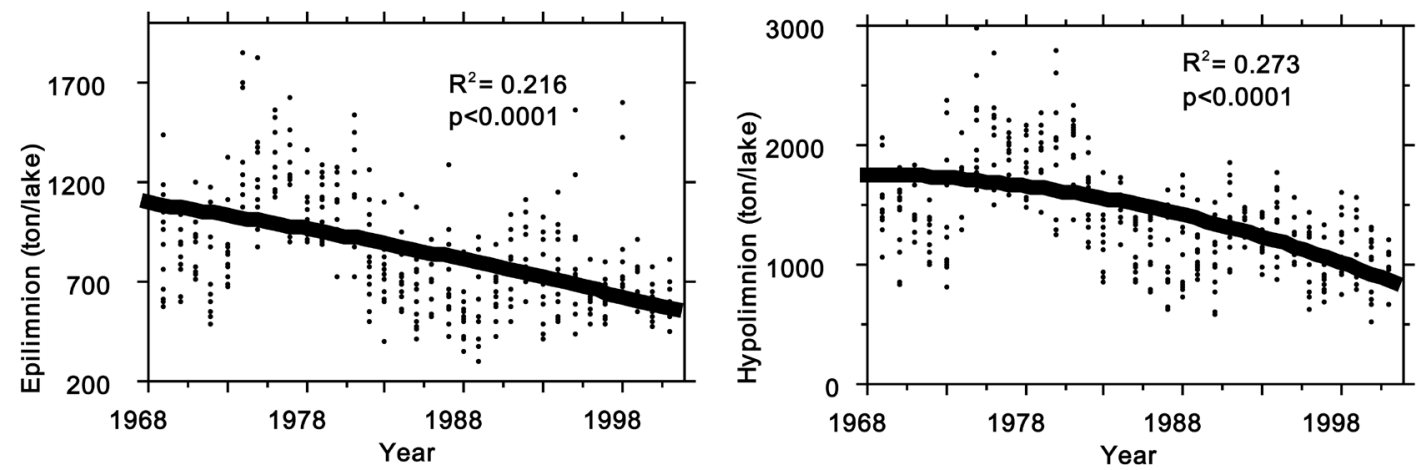

Figure 4. Multi-annual fluctuations of monthly means (1970-2005) of epilimnion (left panel) and hypolimnion (right panel) loads of TN (t/lake); ( $\mathrm{r}^{2}$ and $p$ values are given). Data source: LKDB-KLL. 


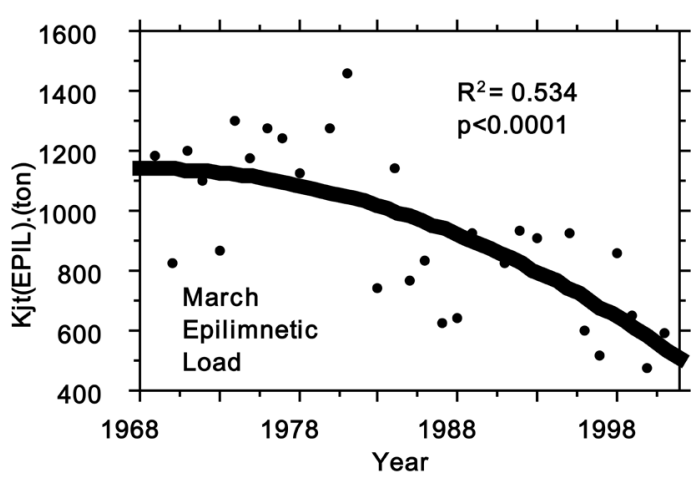

Figure 5. Polynomial regression between monthly loads (t/lake) averages (1969-2005) of Epilimnetic total Kjieldhal Nitrogen in March and years; ( $\mathrm{r}^{2}$ and $p$ values are given). Data source: LKDB-KLL.

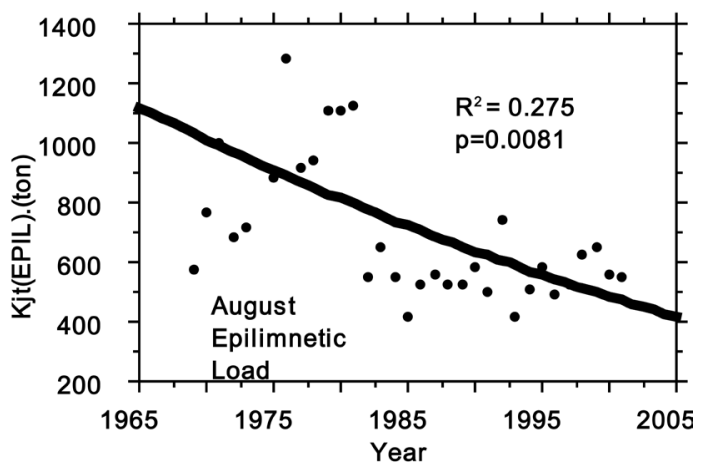

Figure 6. Polynomial regression between Monthly loads (t/lake) averages (1969-2005) of Epilimnetic total Kjieldhal Nitrogen in August and years; $\left(\mathrm{r}^{2}\right.$ and $p$ values are given). Data source: LKDB-KLL.

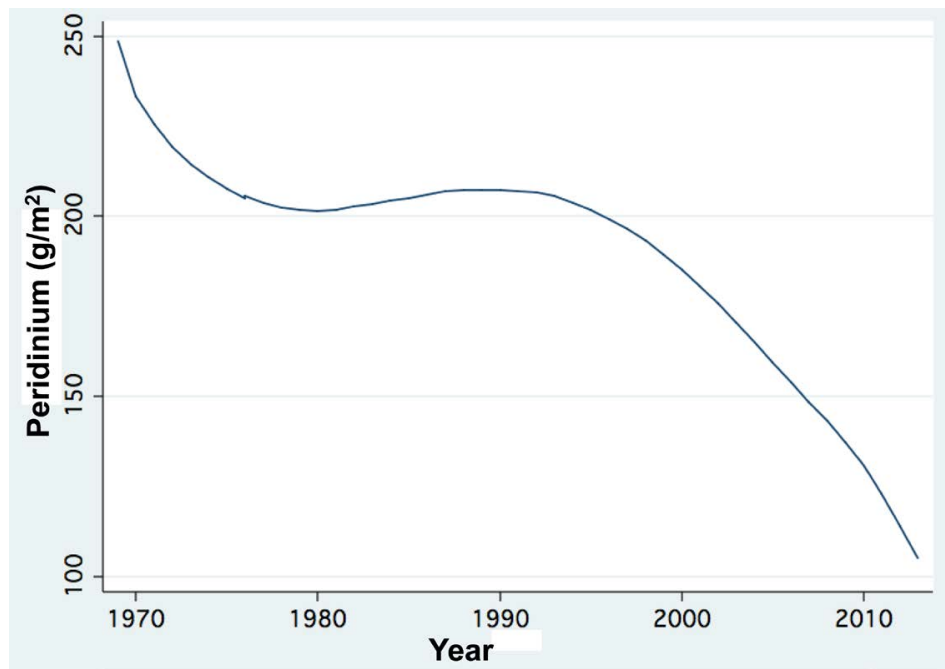

Figure 7. Trend of changes (LOWESS 0.8) of the annual peak biomass $\left(\mathrm{g} / \mathrm{m}^{2}\right)$ of Peridinium during 1969-2013. Data source: LKDB-KKL.

supply to the lake from external sources declined? It has to be considered that the critical point is not Nitrogen in general but the portion of its which is available. Ammonia and organic Nitrogen are more available than nitrate therefore indication of their part in the loads are emphasized. During late 1980s precipitations declined (Figure 10), domestic sewage was eliminated and fish pond effluents reduced. Moreover, the precipitation regime 


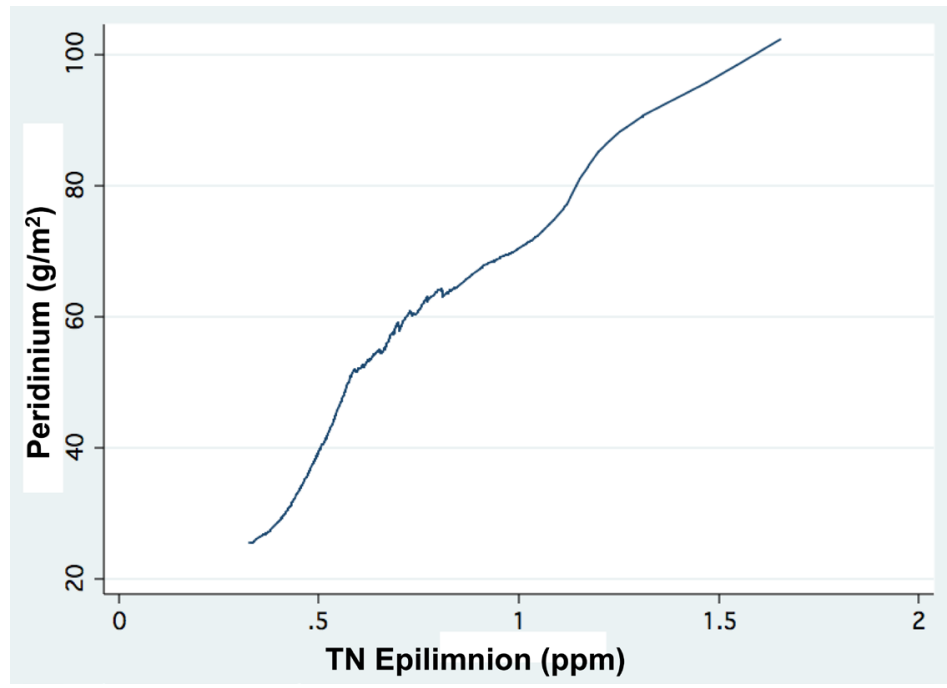

Figure 8. Trend of changes (LOWESS 0.8) of Peridinium monthly mean biomass $\left(\mathrm{g} / \mathrm{m}^{2}\right)$ related to the mean Epilimnetic concentration (ppm) of TN during 1969-2005. Data source: LKDB-KKL.

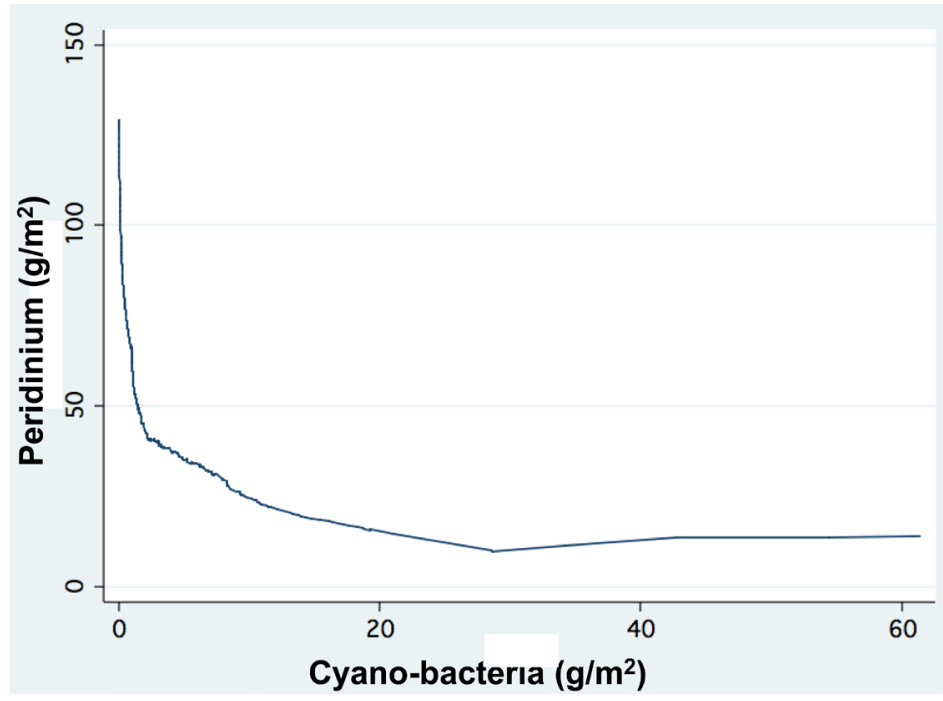

Figure 9. Trend of changes (LOWESS 0.8) of Peridinium monthly mean biomass $\left(\mathrm{g} / \mathrm{m}^{2}\right)$ related to the monthly mean biomass $\left(\mathrm{g} / \mathrm{m}^{2}\right)$ of Cyanobacteria during 1969-2005. Data source: LKDB-KKL.

represented about 15\% decline from mid 1980s (Figure 10) which is also a factor affecting reduction of nutrients inputs. The Kinneret phytoplankton response was Peridinium decline and Cyano-bacteria enhancement [16] [17] (Figures 7-12). The onset of the Cyano-bacteria population came gradually: Until 1996 the peak of Peridinium biomass varied between $100-300 \mathrm{~g}(\mathrm{ww}) / \mathrm{m}^{2}$ and in four years the maximum exceeded 300 $\mathrm{g}(\mathrm{ww}) / \mathrm{m}^{2}$. During 1996-2013 there were only four years with $>300 \mathrm{~g}(\mathrm{ww}) / \mathrm{m}^{2}$ Peridinium and three years with mean value of $100-300 \mathrm{~g}(\mathrm{ww}) / \mathrm{m}^{2}$. In all other 11 years the peak of Peridinium bloom was $<100 \mathrm{~g}(\mathrm{ww}) / \mathrm{m}^{2}$. Regular "Peridinium Year" is indicated by $>100 \mathrm{~g}(\mathrm{ww}) / \mathrm{m}^{2}$ and low level biomass is $<100 \mathrm{~g}(\mathrm{ww}) / \mathrm{m}^{2}$ [10] (Figure 12). Results given in Figure 11 and Figure 12 prominently emphasize the relation between the two dependent factors of Rain gauge and Jordan discharge and independently the intensity of Peridinium bloom. The simultaneous decline of Peridinium biomass and rain gauge and consequently the relation pattern are shown in Figure 11. A period with 11 annual minima of low density and exceptional high ibiomass as affected by floods of Peridinium biomass started is shown in Figure 12. 


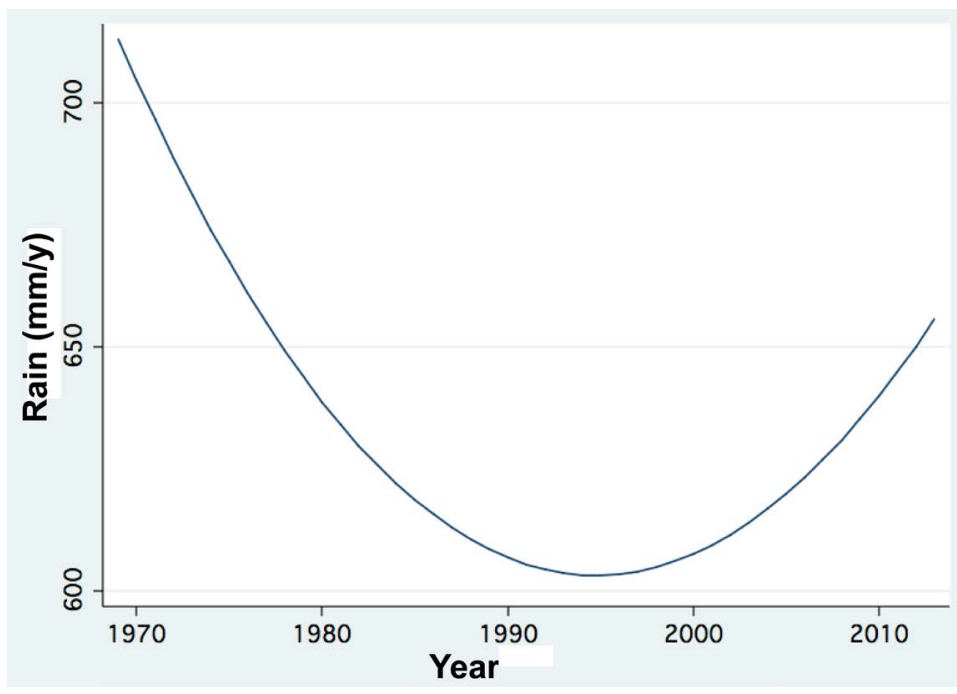

Figure 10. Fractional Polynomial regression between annual rain gauge $(\mathrm{mm} / \mathrm{y})$ in the northern Hula region (Dafna) and years (1969-2013). Data source: M. Peres SHAHAM.

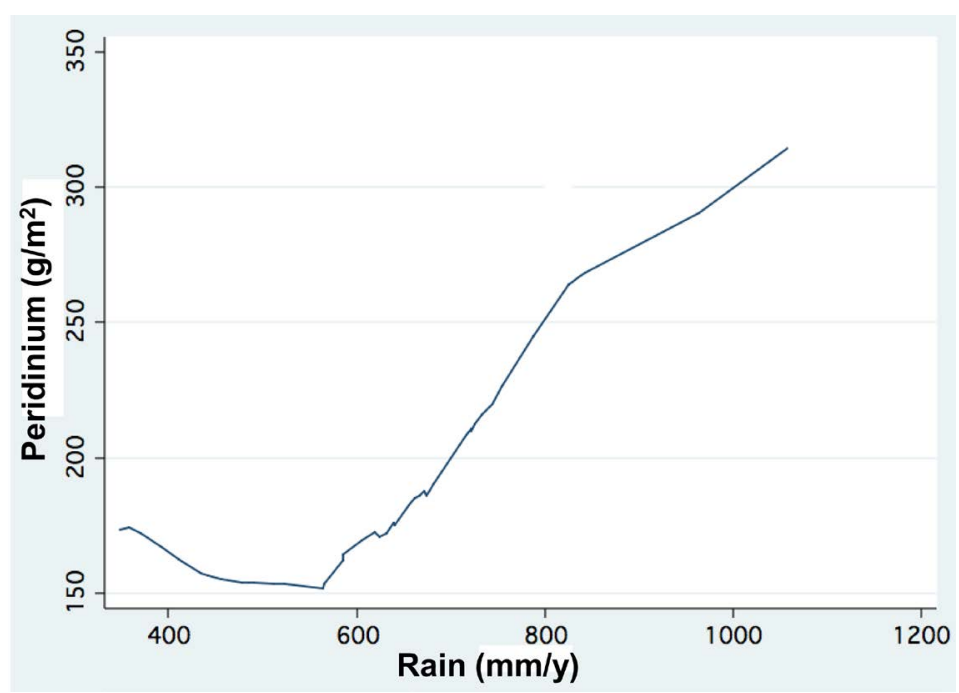

Figure 11. Trend of changes (LOWESS 0.8) of Peridinium biomass $\left(\mathrm{g} / \mathrm{m}^{2}\right)$ related to rain gauge (Dafna, Northern Hula Region) Monthly means, during 1969-2013. Data source: LKDB-KKL and M. Peres SHAHAM.

\section{Discussion}

The impact of the Hula old Lake and Swamps on the Kinneret phytoplankton go through intensity of available Nitrogen supply. The Hula ecosystems were very rich with organic matter and free ammonia. The decay of organic matter produces ammonia. But free ammonia is not the only source of the available ammonia in un-aerobic conditions as existed in the Hula prior to the drainage. Another source is so called Albuminoid ammonia. Albuminoid is a measure of organic matter which may decay. Therefore it is necessary to estimate both kinds of ammonia when nitrogen sources are estimated. Unfortunately, Albuminoid assessment was rarely done on the Hula ecosystem but those which were carried out clearly indicates intensive supply of available ammonia from the Hula to Lake Kinneret. Nitrogen is estimated usually as “Total”, Nitrate, Nitrit, Ammonia but less frequently Albuminoid is measured. Albuminoid ammonia is fairly correct index of the amount of organic matter originated from living and dead organisms so densely populated the Hula swamps.

The progression of Nitrogen deficiency and Phosphorus sufficiency in Lake Kinneret was predicted several 


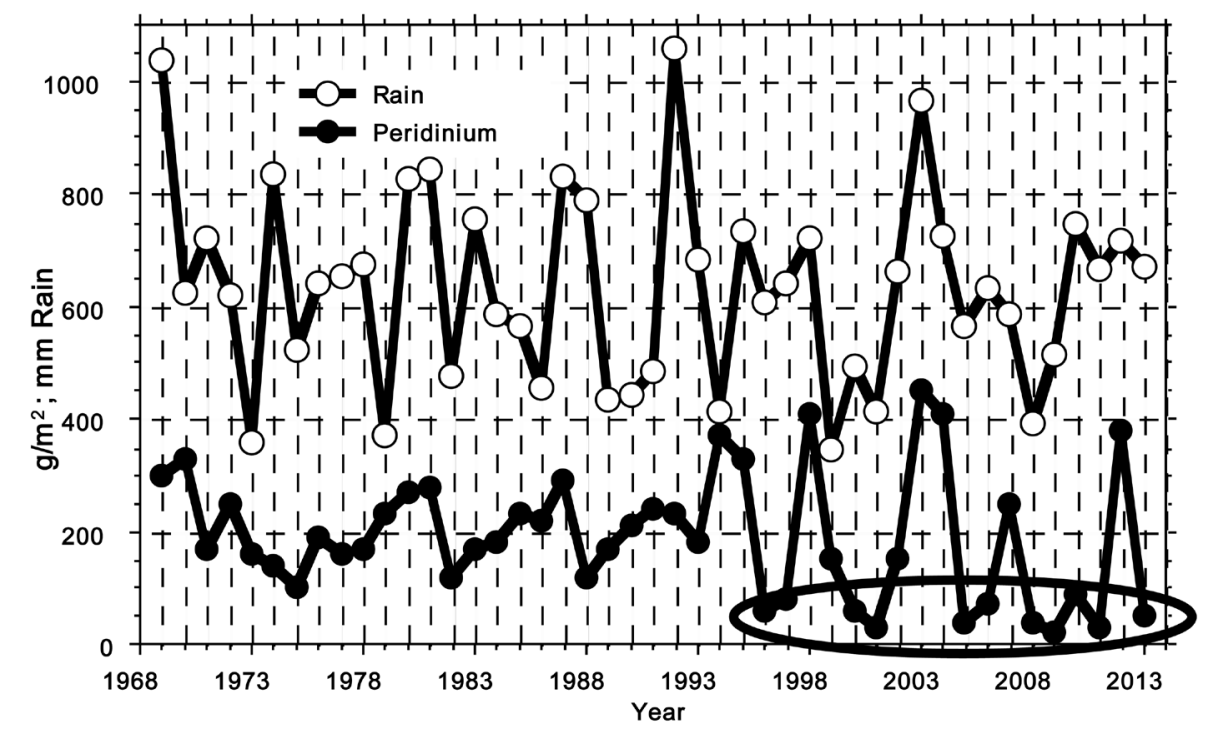

Figure 12. Multiannual fluctuations of Rain Gauge (Dafna) (mm/y) (open cycles) and Peridinium peak Biomass $\left(\mathrm{g} / \mathrm{m}^{2}\right)$ (solid cycles) during 1969-2013. The low level peaks of Peridinium are indicated (solid line surrounded). Data source: LKDB-KKL and M. Peres HAHAM.

years before the outbreak of $\mathrm{N}_{2}$ fixers Cyano-bacterium in the summer of 1994. The changes of the Kinneret ecosystem structure was intensively studied and reported together with evaluations of long and short terms, natural and anthropogenic modifications or exceptional performances. Nevertheless, the impact of Nitrogen as a key factor which originated these fluctuations was neglected. Results presented here justify the attribution of the majority of the impact to Nitrogen availability in Lake Kinneret. Phosphorus supply to the lake biota originate mostly from internal sources which are therefore unlimited and Nitrogen source is mostly external which is strongly affected by climate changes and anthropogenic activities. In previous studies several man made and natural factors were pointed as causative for Lake Kinneret modified structure [3]): Water Level Fluctuations [4] [5] [18] [19], Global warming [20]-[22] fisheries managements, dust storms and deposition, affected by agricultural activity in the Hula Valley or salt diversion. Moreover, several factors were considered as an impact on the intensity of the Peridinium bloom. Some of them are of a biochemical trait, others were related to physical measures like wind, currents, temperatures, treatment of beach vegetation causing damage to dormant cysts of Peridinium and more. Each one of these parameters has probably an impact on the growth rate and/or productivity or even nutrient competition of Peridinium, but less effective as sole effect on the bloom onset or offset as the impact of Nitrogen availability. The outcome of the evaluation done here is the major impact of Nitrogen availability and each one of these other factors are probably effective but of secondary importance as control parameters. Before the Hula drainage its organic matter sources released heavy loads of available Nitrogen as free and albuminoid ammonia. After the Hula Drainage this intensive output of ammonia ceased and Nitrates replaced ammonia as the majority of nitrogen form in the Hula Valley outputs [20] [23] [24]. After the Hula drainage (1950s) organic substances, organic nitrogen, free and albuminoid ammonia supply came from domestic treated sewage and fishpond effluents. When these sources were eliminated, the Nitrogen requirements of Peridinium were insufficient and its blooms diminished. Exceptional blooms of Peridinium bloom were due to heavy rain gauge accompanied by Nitrogen erosion and consequently input into the lake. It is suggested that in spite of Nitrate form dominance in those winter floods, the high quantity enabled Peridinium bloom forming. The replacement of Peridinium by Cyano-bacteria is reasonable due to their ability to utilize atmospheric $\mathrm{N}_{2}$ without the dependence on drainage basin supply.

\section{Summary}

The major modifications of the Kinneret, (lake and drainage basin), ecosystem structure are closely related to the decline of available Nitrogen supply from the basin to the lake. Before the drainage of the old Lake Hula and surrounding swamps, the lake was supplied by bio-available Nitrogen, Ammonia. After the Hula drainage, the 
dominant form of Nitrogen fluxed from the Hula Valley was changed to Nitrate which is less available to algae in general and especially to the bloom forming Peridinium then Ammonia. Nevertheless, other sources of ammonia, domestic sewage and fishpond effluents covered the Peridinium demands to produce a yearly blooms. When these sources of ammonia were eliminated, the Kinneret ecosystem shifted from Phosphorus to Nitrogen limitation. Peridinium blooms were replaced by blooms of Cyano-bacteria. Other compartments of the ecosystem also modified, such as feeding behavior of the native fish Sarotherodon galilaeus. The removal of sewage (nutrients and pathogenic factors) from the inputs of rivers, man-made and natural Lakes is ultimately accepted and instructed as a key factor aimed at prevention of water quality deterioration (eutrophication). In this paper, the reversal option is discussed: domestic sewage and fish-pond effluents contributors of ammonia supporting prevention of water quality deterioration in Lake Kinneret.

\section{Acknowledgements}

Appreciative thanks for the collaborative discussions and open data source are due to three organizations: Kinneret Authority (KA) - Water authority, Mekorot Water Supply Company (MWSC) and Kinneret Limnological Laboratory (KLL-LKBD) - Israel Oceanographic and Limnological Research Company.

\section{References}

[1] Gophen, M. (2002) The Management of Lake Kinneret (Israel): Water Supply, Water Quality and Food Web Structure Perspectives. Proceedings of the Water and Environmental Research ICWRER, 2, 275-285.

[2] Gophen, M. (2003) Water Quality Management in Lake Kinneret (Israel): Hydrological and Food Web Perspectives. Journal of Limnology, 62, 91-101. http://dx.doi.org/10.4081/jlimnol.2003.s1.91

[3] Gophen, M. (2000) Lake Kinneret (Israel) Ecosystem: Long-Term Instability or Resiliency? Water, Air, and Soil Pollution, Special Section: Environmental Challenges, 123, 323-335.

[4] Gophen, M. (2008) Long Term (1970-2001) Eco-Hydrological Processes in Lake Kinneret and Its Watershed. In: Zereini, H., Ed., Climatic Changes and Water Resources in the Middle East and in North Africa, Invited Chapter, Springer, Berlin, 373-402. http://dx.doi.org/10.1007/978-3-540-85047-2_24

[5] Gophen, M. (2008) Climatological and Anthropogenic Influence on Biodiversity in Lake Kinneret (Israel). Verhandlungen des Internationalen Verein Limnologie, 30, 1278-1802.

[6] Gophen, M. (2004) Hydrology and Management of Lake Kinneret Aimed at Water Quality Protection. In: Zreiny, F. and Jaeschke, W., Eds., Water in the Middle East and in North Africa: Resources, Protection, and Management, Springer-Verlag, Berlin, 207-226. http://dx.doi.org/10.1007/978-3-662-10866-6_18

[7] Gophen, M. (2004) Ecohydrological Management of Lake Kinneret: A Case Study. Ecohydrology and Hydrobiology, 4, 397-408.

[8] (2004-2013) KA (Kinneret Authority-Water Authority). In: Green, P., Ed., Annual Reports of Activity.

[9] MWSC, Mekorot Water Supply Company (1969-2013) Annual Reports. In: Geifman, Y. and Rom, M., Eds.

[10] LKBD-KKL (1969-2013) Lake Kinneret Data Base. In: Berman, T., Serruya, C., Gophen, M., Sukenik, A. and Zohary, T., Eds., Annual Reports.

[11] Jones, R.F. (1940) Report of the Percy Sladen Expedition to Lake Huleh: A Contribution to the Study of the Fresh Waters of Palestine. I: The Plant Ecology of the District. Journal of Ecology, 28, 357-376. http://dx.doi.org/10.2307/2256234

[12] Dimentman, C., Bromley, H.J. and Por, F.D. (1992) Lake Hula. The Israeli Academy of Sciences and Hummanities, Jerusalem, $170 \mathrm{p}$.

[13] Rodhe, W. (1978) Peridinium: Growth Characteristics. In: Serruya, C., Ed., Lake Kinneret: Monographiae Biologicae, 32, 275-284.

[14] Pollingher, U. (1978) Peridinium: Life Cycle. In: Serruya, C., Ed., Lake Kinneret: Monographiae Biologicae, 32, 271274.

[15] Pollingher, U. and Serruya, C. (1978) Pewridinium: Growth Pattern in the Lake. In: Serruya, C., Ed., Lake Kinneret: Monographiae Biologicae, 32, 285-290.

[16] Gophen, M., Smith, V.H., Nishri, A. and Threlkeld, S.T. (1999) Nitrogen Deficiency, Phosphorus Sufficiency, and the Invasion of Lake Kinneret, Israel, by $\mathrm{N}_{2}$-Fixing Cyanobacterium Aphanizomenon Ovalisporum. Aquatic Sciences, 61, 293-306. http://dx.doi.org/10.1007/PL00001326

[17] Gophen, M. (2011) The Cladoceran Trophic Status in the Nitrogen Limited Ecosystem of Lake Kinneret (Israel). 
Journal of Environmental Biology, 32, 455-462.

[18] Serruya, C. and Pollingher, U. (1977) Lowering of Water Level and Algal Biomass in Lake Kinneret. Hydrobiologia, 54, 73-80. http://dx.doi.org/10.1007/BF00018773

[19] Gophen, M. (2014) The Impact of Water Level Decline on Water Quality in the Epilimnion of Lake Kinneret (Israel): Perennial Perspectives. Open Journal of Ecology, 4, 892-906. http://dx.doi.org/10.4236/oje.2014.414075

[20] Gophen, M. (2014) Land-Use, Albedo and Air Temperature Changes in the Hula Valley (Israel) during $1946-2008$. Open Journal of Modern Hydrology, 4, 101-111. http://dx.doi.org/10.4236/ojmh.2014.44010

[21] Gophen, M. (2013) The Impact of Temperature Elevation on the Decline of Cyclopoid Population in Lake Kinneret (Israel). The Journal of Ecology, Photon, 107, 23-239.

[22] Gophen, M. (2015) Thermal Preference by Mesocyclops ogunnus (Onabamiro 1957). Open Journal of Ecology, 5, 15-21. http://dx.doi.org/10.4236/oje.2015.52002

[23] Gophen, M. (2015) Management Improvement of the Agmon Wetlands System (Hula Valley, Israel) Aimed at Enhancement of Bird Populations and Kinneret Protection. Open Journal of Modern Hydrology, 5, 1-9. http://dx.doi.org/10.4236/ojmh.2015.51001

[24] Gophen, M., Meron, M., Orlov-Levin, V. and Tsipris, Y. (2014) Seasonal and Spatial Distribution of N \& P Substances in the Hula Valley (Israel) Subterranean. Open Journal of Modern Hydrology, 4, 121-131. http://dx.doi.org/10.4236/ojmh.2014.44012 